\title{
Assessment of Positive Psychology Course according to Comments and Life Satisfaction Levels of Counselor Candidates
}

\author{
Aslı Uz Baş \\ Correspondence: Aslı Uz Baş, Buca Faculty of Education, Dokuz Eylül University, İzmir, 35150, Turkey \\ Received: November 11, 2015 \\ Accepted: November 23, $2015 \quad$ Available online: December 1, 2015 \\ doi:10.11114/jets.v4i3.1195 \\ URL: http://dx.doi.org/10.11114/jets.v4i3.1195
}

\begin{abstract}
The purpose of this study was to assess the "Positive Psychology" course according to comments and life satisfaction levels of counselor candidates. The course was offered in Guidance and Psychological Counseling undergraduate program as an elective course. The participants of the study were 56 senior undergraduate students attended Guidance and Psychological Counseling program in Turkey. Findings showed that counselor candidates think that the Positive Psychology course contributed to their vocational and personal / social developments. They also stated that the course should be taught in counselor training. Finally, the results demonstrated that the Positive Psychology course was effective for increasing life satisfaction scores of counselor candidates.
\end{abstract}

Keywords: positive psychology course, counselor training, life satisfaction

\section{Introduction}

Unlike psychotherapy, counseling profession was historically developed from guidance movement. But nowadays counseling activities include focusing on growing and well-being services, and intervening to mental health disorders as well (Arıcıoğlu, 2013). Counseling services have four main functions including crisis intervention, remediation, development and prevention. It is seen nowadays, there is a tendency toward preventive and developmental services for counseling (Korkut, 2004, p. 5). Similarly counseling and guidance services presented in the schools are based on comprehensive and developmental approach in our days. Comprehensive and developmental guidance approach has a developer and preventive nature.

Similar to the recent advances in the field of counseling and guidance, as a new field of psychology, "positive psychology" which focuses to develop human strengths against the pathology focused models made a progress nowadays. Similar tendency is seen in both psychology and guidance, even though they have been declared in a different terminology.

Positive psychology movement has been started with the opening speech of Martin E. P. Seligman, as the president of American Psychological Association in 1998 (Grenville-Cleave, 2012, p. 2). Seligman has evaluated the issues of psychology science from past to present with a critical approach in his historical speech. Psychology science has been an important science which focused on treating mental illness after the World War II but did not present knowledge of what makes life worth living (Seligman and Csikszentmihalyi, 2000). This situation caused the omission of development and related issues of healthy individuals. Purpose of positive psychology is not only to solve the problems in the life, but also to focus on human strengths. Seligman (1998) stated that "treatment is not just fixing what is broken, it is nurturing what is best within ourselves." Positive psychology field has shown an extraordinary development since it has been established and many works have been published about the subject, many conferences have been arranged and started to be presented as a course in the universities (Gable and Haidt, 2005).

Positive psychology is an umbrella concept which contains positive emotions, positive character traits, and enabling organizations (Seligman, Steen, Park, and Peterson, 2005). Positive psychology focuses on main concepts such as happiness, positive emotions, flow experience, meaning of life and handles these issues with empirical research. However humanistic theorists such as Rogers and Maslow also have focused on human strengths, positive psychology uses the empirical research differently from the philosophical nature of humanistic psychology.

The concepts which have been handled by positive psychologists have important implications for the field of counseling and guidance. Counseling and guidance includes problem solving interventions as well as preventive and developer activities. Egan (2011, p. 24) stated that there are two main purpose of counseling. First one is to help the clients to 
solve their problems in order to live effectively and the second one is to develop opportunities. Counselors in Turkey works mainly in the school environments currently even they have the possibilities to work in the environments such as health, industry, social welfare except the education environment. Schools are consisted of normal children and adolescents predominantly. In this situation the importance of counselors' information about clinical psychology is not denied but also they need to be well equipped in the field of understanding the normal growth and development and beyond it the human strengths and well-being. Eryllmaz (2012) suggested that the most important occupation is counseling and guidance in the field of education which will carry the findings of positive psychology either to the education and counseling practises; counselors working in educational organizations has a main responsibility for developing the strengths of students and their abilities to forward these positive emotions to their lives.

Fulmer (2015) suggested that positive psychology could be applied in the counseling field through different ways. Firstly counselors more frequently employ a strengths-based approach with their clients. School counselors, career counselors and mental health counselors could also use strengths-based modalities and positive psychology could be integrated into these approaches. Also positive psychology informs the counselors about human strengths and their correlates. Positive psychology is one of the approaches which could be benefited by school counselors who work with children and adolescents. Seligman and his colleagues (2009) stated that well-being should be taught in the schools and school-based positive psychology programs produce positive and reliable improvements in students' well-being.

While the positive psychologists are trying to determine the variables which effects the well-being of people by the empirical studies, at the same time they are trying to deliver intervention approaches for better living of the people (such as more satisfying of life, to be more optimist, to experience the positive emotions often). Many studies evaluating the effects of positive psychology interventions revealed that positive psychology interventions increased the well-being (Mongrain and Anselmo-Matthews, 2012; Seligman et al., 2005). Diener and Chan (2011) suggested that subjective well-being contribute to health and longevity. Above mentioned research findings indicate that positive psychology interventions are very important either in educational environments or in counseling environments.

Positive psychology movement has been one of the research areas which attracts attention in Turkey nowadays. Many studies presented at $13^{\text {th }}$ National Psychological Counseling and Guidance Congress were about positive psychology. Positive psychology courses have been offered at undergraduate psychology programs in various universities. On the other hand positive psychology teaching is not common in the GPC undergraduate and postgraduate programs in Turkey. When considering the implications of positive psychology science for the field of counseling and guidance, even to place this lesson as an elective course in these education environments will contribute to the counselor training programs. Positive psychology has a feature to support the counselor candidates' counseling skills and to expand their approaches for helping, and also may enhance their personal and social development. Positive psychology course which was given in Harvard University in 2006 was the most popular course of the university with the participation of more than 800 students. So it was the most popular course of Harvard University in its history (Froh and Parks, 2013, p.3). One recent study conducted in Turkey (Koydemir and Kahraman, 2015) showed that an elective course named "Happiness and Well-Being Seminar" which handles positive psychology subjects caused increased scores of life satisfaction, life engagement, and hope among university students.

\subsection{The Aim of the Study}

The purpose of this study is to assess the "Positive Psychology" course which was offered in GPC undergraduate program as an elective course according to comments and life satisfaction levels of counselor candidates. Counselor trainers and school counselors working in the field may benefit from the findings of this study.

\section{Method}

\subsection{Research Design}

In this study a mixed method research design was used with quantitative and qualitative research methods. Mixed method includes to combine the quantitative and qualitative research techniques and methods into a single study (Leech and Onwuegbuzie, 2007).

\subsection{Participants}

The participants of the study were 56 senior undergraduate students attended GPC program at Dokuz Eylül University in İzmir, Turkey. Participant ages ranged from 20 to 25 years, $79 \%$ were female, and $21 \%$ were male.

\subsection{Measures}

The Satisfaction with Life Scale (SWLS; Diener, Emmons, Larsen, and Griffin, 1985): The SWSL is a 5 -item scale designed to measure global cognitive judgments of one's life satisfaction. Participants indicate how much they agree or disagree with each of the 5 items using a 7 -point scale that ranges from 7 strongly agree to 1 strongly disagree. Higher 
scores indicate higher levels of satisfaction with life. The scale was adapted into Turkish by Köker (1991) and Yetim (1993). The Cronbach's alpha coefficient of the scale was found as .86 (Yetim, 1993).

Positive psychology course evaluation form: An evaluation form was developed by the researcher in order to obtain the comments of counselor candidates about positive psychology course. This evaluation form was applied to the students after the completion of course. Evaluation form consists of six questions; three of them were closed-ended questions, and three of them were open-ended questions. In the closed-ended questions, students was required to answer the question about the existing of positive psychology course in the GPC program and if this course contribute to their vocational and personal / social development by giving the numbers from 1 to 5 scale. ( $1=$ I strongly agree $5=\mathrm{I}$ strongly disagree). In the open-ended questions, first two questions were asked in order to understand vocational and personal/social developmental effects of course over the students. Third open ended question was about the students' positive or negative views about the course intent, teaching methods, and the instructor. For the content validity of the form, the researcher has asked for the experts' opinions on the questions in the form. In order to verify the external reliability of the form, data collection procedures and analysis were described in as much detail as possible. For the internal validity, the findings obtained have presented objectively without accompanying interpretation.

\subsection{Procedure}

Positive psychology course was offered at Dokuz Eylül University for the first time during the 2014-2015 Fall term. The elective course was designed for senior GPC students. The objective of the course was to increase the student's sufficiency in the field of using positive psychology in counseling and guidance services by informing the students about the content of positive psychology approach. Seligman's (2012) five dimensional well-being model was based during the preparing of course content. Well-being model of Seligman (PERMA) consists of five components. These components are positive emotions, engagement, relationships, meaning and achievement. Content and method about the lesson was presented in Table 1. Teaching methods of the course include didactical methods such as lecturing and class discussion, and experiential activities such as group activities and homework. Didactical approach was limited in the structuring of the each lessons and concentrated on experiential activities. After the end of each course a relevant homework was given to the students. First section of following course was reserved for sharing the homework. Students were required to prepare a personal well-being portfolio including weekly homeworks and deliver it to the instructor at the end of the term.

Table 1. Course Outline

\begin{tabular}{|c|c|c|}
\hline Week & Content & Process \\
\hline 1 & Course introduction & Lecture \\
\hline 2 & $\begin{array}{l}\text { Positive psychology movement, aim and scope } \\
\text { Happiness and subjective well-being }\end{array}$ & $\begin{array}{l}\text { Class discussion } \\
\text { Lecture } \\
\text { Class discussion }\end{array}$ \\
\hline 3 & Seligman's well-being model (PERMA) & $\begin{array}{l}\text { Homework } \\
\text { Lecture }\end{array}$ \\
\hline & & $\begin{array}{l}\text { Class discussion } \\
\text { Homework }\end{array}$ \\
\hline 4 & Barriers to well-being & $\begin{array}{l}\text { Lecture } \\
\text { Class discussion }\end{array}$ \\
\hline 5 & Positive emotions & $\begin{array}{l}\text { Homework } \\
\text { Lecture } \\
\text { Class discussion }\end{array}$ \\
\hline 6-7 & Flow & $\begin{array}{l}\text { Homework } \\
\text { Lecture }\end{array}$ \\
\hline & & $\begin{array}{l}\text { Class discussion } \\
\text { Homework }\end{array}$ \\
\hline 8 & Positive relationships & $\begin{array}{l}\text { Lecture } \\
\text { Class discussion } \\
\text { Group activities } \\
\text { Homework }\end{array}$ \\
\hline $9-10$ & Meaning and purpose of life & $\begin{array}{l}\text { Lecture } \\
\text { Class discussion } \\
\text { Homework }\end{array}$ \\
\hline 11 & Achievement & $\begin{array}{l}\text { Lecture } \\
\text { Class discussion } \\
\text { Homework }\end{array}$ \\
\hline 12 & Resilience & $\begin{array}{l}\text { Lecture } \\
\text { Class discussion } \\
\text { Homework }\end{array}$ \\
\hline 13 & Choice & $\begin{array}{l}\text { Lecture } \\
\text { Class discussion } \\
\text { Homework }\end{array}$ \\
\hline 14 & Using of positive psychology in counseling and guidance services & $\begin{array}{l}\text { Lecture } \\
\text { Class discussion }\end{array}$ \\
\hline
\end{tabular}




\subsection{Data Analysis}

In data analysis procedure, quantitative and qualitative data were analyzed separately. Quantitative data regarding counselors candidates' comments about the course was evaluated by using frequency and percentage analysis. Qualitative data which have been collected from the open-ended questions' answers were evaluated by the content method. Data which has been gathered in this purpose was organized in reasonable conditions and the theme which explains the data were determined (Yıldırım and Şimşek, 2005). Also the answers of participants for the open-ended questions were submitted directly quotation method. Finally, data regarding life satisfaction levels of counselor candidates was evaluated by using one-way analysis of variance (ANOVA) for repeated measures technique. It was examined whether there is a significant difference between the pre-test and post-test life satisfaction mean scores of the counselor candidates who have trained of positive psychology course in. Quantitative data was processing using the Statistical Package for the Social Sciences (SPSS, version 15.0 for Windows).

\section{Results}

Research findings will be handled in two titles. Firstly counselor candidates' comments on the Positive Psychology course will be presented. Then, the findings about life satisfaction levels of counselor candidates will be illustrated.

\subsection{Findings of Counselor Candidates' Comments on the Positive Psychology Course}

Counselor candidates' comments on the Positive Psychology course were evaluated by the Positive Psychology Evaluation Form. The form includes both closed-ended and open-ended questions. Firstly, quantitative data, the answers given to the closed-ended questions will be given place in the presentation of findings. Secondly, qualitative data of answers of open-ended questions will be presented.

Table 2. Comments on teaching positive psychology as a course in GPC undergraduate program

\begin{tabular}{llll}
\hline "Positive Psychology course should be taught in counseling & $\mathrm{n}$ & $\%$ \\
program" & & 45 & 80.3 \\
\hline Strongly agree & & 10 & 17.9 \\
Agree & & 1 & 1.8 \\
Neither agree nor disagree & - & - & - \\
Disagree & - & - & - \\
\hline
\end{tabular}

As seen on Table 2, most of the students (80.3\%) strongly agree for the view of Positive Psychology Course should be taught in GPC undergraduate program, when considered that $18 \%$ of the students agree with this view approximately. It means nearly all of the students would like to see this Positive Psychology course in GPC undergraduate program.

Table 3. Counselor candidates' comments on the effects of Positive Psychology course on vocational development

\begin{tabular}{lll}
\hline "Positive Psychology course improved my vocational development." & $\mathrm{n}$ & $\%$ \\
\hline Strongly agree & 43 & 76.8 \\
Agree & 13 & 23.2 \\
Neither agree nor disagree & - & - \\
Disagree & - & - \\
Strongly disagree & - & - \\
\hline
\end{tabular}

According to Table 3, all of the students think that Positive Psychology course contributes to their vocational development. Nearly three fourths of these students (76.8\%) strongly agree with this opinion, one fourths (23.3\%) agree with this opinion.

Table 4. Counselor candidates' comments on the effects of Positive Psychology course on personal / social development

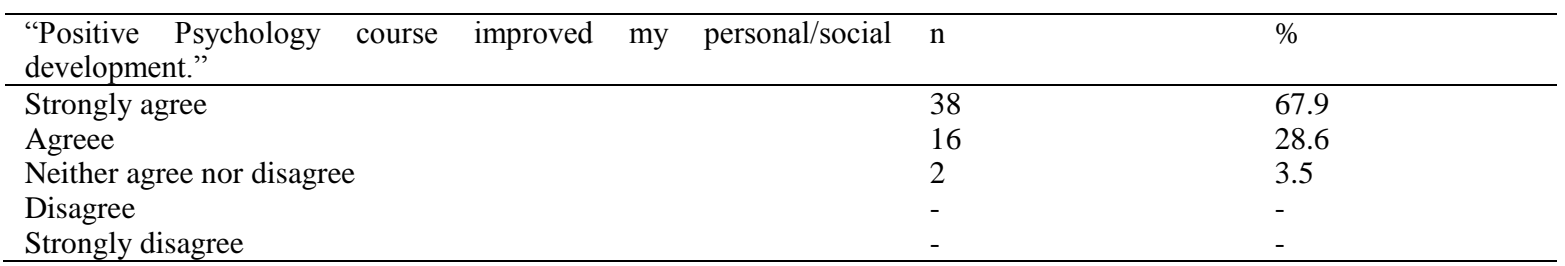

According to Table 4, nearly all of the students think that Positive Psychology course contributes to their personal / social development. Only 2 students $(3.5 \%)$ stated that they agree partially.

In the present study, views of students about the course have been also evaluated with the open-ended questions by Positive Psychology Evaluation Form. Answers of students to the open-ended questions will be presented below under three titles. These are respectively views of counselor candidates regarding the effects of Positive Psychology course on their vocational development, views regarding the effects of Positive Psychology course on their personal / social development, and views regarding the content, method and instructor of course. 
Counselor candidates' comments about the effects of Positive Psychology course on their vocational development: When the answers of participants were evaluated with content analysis, seven different themes were reached. These themes are respectively to their repeating frequency: Gaining awareness to focus on positive features while working with the clients (24 participants), learning how to increase the well-being of clients (17 participants), learning how to enhance human strengths (13 participants), gaining a different view of counseling process ( 8 participants), perceiving the happiness concept in a different way (5 participants), and learning how to handle the negative emotions (4 participants).

Some answers of counselor candidates about the effects of Positive Psychology course on their vocational development:

"I have perceived my occupation to correct the worse one until today. I have understood by this lesson that, to improve the good one is also a part of my occupation." (Male, 21)

"I think that there will be positive reflections of this course relating the communication of us with the clients by this course, I think this lesson's contribution is really great for me to assist our clients during assisting them to evaluate the well-being wheel, and find the meaning of life" (Girl, 21)

Counselor candidates' comments about the effects of Positive Psychology course on their personal / social development: When the answers of students were evaluated with content analysis, eight different themes were reached. These themes are respectively to their repeating frequency: increasing the self-awareness (34 participants), increasing their own well-being (32 participants), changing their perceptions about happiness (13 participants), improving their interpersonal relationships ( 9 participants), gaining new perspectives ( 8 participants), becoming clearer about meaning of life (6 participants), changing their views of other people positively (1 participant), and enhancing their self-perception (1 participant).

Some answers of counselor candidates about the effects of Positive Psychology course on their personal / social development:

"I have found a chance to think about the happiness concept when I started to take this course. These days, happiness was seen to me a point where is very difficult to reach. But I found the chance to measure myself when we were required to write the things what makes us happier. My lists were drag on. I have seen there are many activities which makes me happier when I take a look to the paper and surprised. This course made me aware about to see the positive sides of me instead of focusing on my negative sides only. I can say, I am more polite and tolerant toward myself." (Girl, 21)

I noticed that there is no need to have great things to get happier and noticed that happiness is an emotion which is lived by striving more than having it. I learnt to struggle with hard living conditions. Thought about the meaning perceive of my life and started to consist it graded. I tried to increase my flow experiences. I learnt to know the other party in inter personal relationships and learnt to react positively when they feel happy too. I have gained more awareness and control on my life. (Girl, 21)

Counselor candidates' comments on the content, teaching methods and instructor of course: When the answers of students about the content of the course were evaluated with content analysis, three different themes were reached. These themes are respectively to their repeating frequency: being glad about the content of the course (45 participants), seeing similarities between the course content and real-life experiences ( 8 participants), and recommending that positive psychology course be a compulsory lesson (6 participants). When the answers of students about the method of course were evaluated with content analysis, four different themes were reached these themes are respectively to their repeating frequency; being glad about teaching method of course (45 participants), thinking that homework are so beneficial (13 participants), thinking that in-class discussions are beneficial ( 2 participants), and recommending that experiential activities should be increase (1 participants). When the answers of students about the instructor of course were evaluated with content analysis, two different themes were reached. These themes are respectively to their repeating frequency; being glad about the instructor's attitudes toward teaching (36 participants) and finding consistency between the attitudes of instructor and the content of the course (19 participants).

Some answers of counselor candidates about the content, method and instructor are presented below:

This course was really different from the other courses we have taken for the last 4 years. We have focused on the problems from the beginning and we tried to solve the problems. But firstly we have focused on positive in this course and noticed that we can solve the problems by focusing on positive. It was a course which have motivated me and increased my awareness. I think that course should be given in third class not in fourth class and it should be an obligatory course not an elective lesson. The clause of elective causes some students to perceive this course as a non-important course because. (Girl, 21)

The content of lesson has never made me bored due to including the examples in our life. In contrary the homework which was given us was not considered as homework for me I noticed that homework was an activity to know myself 
better. I noticed to learn new things with these homework's. Determined what affects my well being. And felt myself positive by relating these concepts. (Girl, 21)

\subsection{Findings about Life Satisfaction Levels of Counselor Candidates}

In order to evaluate the effects of the Positive Psychology course on the life satisfaction levels of counselor candidates, the Satisfaction with Life Scale has been implemented before the start of the course and after completing the course. The mean pre- and post-test scores and standard deviations of counselor candidates were presented in Table 5.

Table 5. Pre-test and post-test life satisfaction mean scores and standard deviations of counselor candidates

\begin{tabular}{llllll}
\hline & \multicolumn{1}{c}{ Pre-Test } & Post-Test & \\
& $\mathrm{n}$ & $M$ & $S D$ & $M$ & $S D$ \\
\cline { 2 - 5 } & & & & & \\
Life satisfaction & 52 & 23.769 & 4.945 & 25.942 & 5.685 \\
\hline
\end{tabular}

As illustrated by the data presented in Table 5, the mean scores for life satisfaction were $23.76(S D=4.94)$ for the pre-test measurement and $25.94(S D=5.68)$ for the post-test measurement. In order to determine whether there is a significant difference between pre-test and post-test mean scores for the students who competed the Positive Psychology course, one-way ANOVA for repeated measures technique was used. Results have been presented in Table 6.

Table 6. ANOVA results of life satisfaction pre- and post-test mean scores of counselor candidates

\begin{tabular}{llllll}
\hline Source & Sum of Squares & df & Mean Square & F & P \\
\hline Within Subjects & 2435.337 & 51 & 47.752 & & \\
Measurement & $\mathbf{1 2 2 . 7 7 9}$ & $\mathbf{1}$ & $\mathbf{1 2 2 . 7 7 9}$ & $\mathbf{1 3 . 5 9 1}$ & $\mathbf{. 0 0 1}$ \\
Error & 460.721 & 51 & 9.034 & & \\
Total & 3018.837 & 103 & & &
\end{tabular}

As illustrated in Table 6, the one-way ANOVA demonstrated a statistically significant difference between pre-test and pos-test life satisfaction scores $(\mathrm{F}=13591 ; \mathrm{df}=51 ; p<.05)$ The results demonstrated that the Positive Psychology course was effective for increasing life satisfaction scores of counselor candidates.

\section{Discussion}

The purpose of this study was to assess Positive Psychology course which is a newly developed elective course offered for GPC undergraduate program according to comments and life satisfaction levels of counselors candidates.

Findings about the answers of counselor candidates for the closed-ended questions showed that most of the students thought that the positive psychology course should be taught in counseling program; similarly most of the students stated that the Positive Psychology course contribute to their vocational developments as well as their personal and social developments. Some review studies showed that the positive psychology movement has grown so quickly in recent years and courses in positive psychology have sprung up in universities and high schools (Csikszentmihalyi, 2009; Gable and Haidt, 2005). Also in the universities where the positive psychology course is taught, students take much interest in this course (Froh and Parks, 2013). The current findings are supported the notion that positive psychology should be taught in counseling programs.

Open-ended questions which were answered by counselor candidates were including the views of students about the contribution of Positive Psychology course to their personal and social developments. Counselor candidates explained that positive psychology course has contributed to their personal and social developments in different ways. When examining the answers of students, it has been determined that most of the courses in counseling program were focusing on to understand the problems of clients and to solve these problems, by this course they have learned to focus on the strengths of the clients. In addition they notice that the information they have been given in this course will affect them in their foregoing life vocational developments. And they stated that by this course students have learned to know the barriers to their well-being and have learned the ways how to feel positive. The quantitative and qualitative answers of the questions of the open-ended and closed-ended questions showed similar features that positive psychology course affected their vocational developmets and improved their personal and social developments. In fact, positive psychology can integrate into the field of school counseling in different ways (Eryllmaz, 2012; Fulmer, 2015). Terjesen, Jacofsky Froh and Digiuseppe (2005) stated that school psychologists may achieve the goal that every child to succeed to the fullest potential through positive psychology applications. The findings of the study supported the notion that counselor candidates need to learn about positive psychology and its applications in school counseling. 
In the current study, the effects of the Positive Psychology course were also assessed according to the life satisfaction scores of counselor candidates. In order to determine whether there is a significant difference between the pre-test and post-test life satisfaction mean scores of the counselor candidates, one-way ANOVA for repeated measures technique was used. The results demonstrated that the post-test life satisfaction scores of counselor candidates were significantly higher than the pre-test scores. In the other words, Positive Psychology course was effective for increasing life satisfaction scores of counselor candidates. The current finding was similar to a recent study conducted in Turkey (Koydemir and Kahraman, 2015). They found that the "Happiness and Well-Being Seminar" course which handles positive psychology subjects caused increased scores of life satisfaction, life engagement, and hope among university students. Also some previous studies showed that positive psychology applications increase the participant's well-being and life satisfaction levels (Mongrain and Anselmo-Matthews, 2012; Seligman et al., 2005).

When the results obtained from the research is evaluated as a whole, Positive Psychology course which has been taught to the senior undergraduate students attended GPC program was found to be beneficial and be effective according to the comments of counselor candidates and their life satisfaction scores. This course is recommended for counseling students in other universities in respect to support the improvements of counselor candidates. The field of positive psychology may provide additional knowledge and views about helping styles for counselor candidates. Positive Psychology has a variety of application fields in the schools. Seligman and his colleagues (2009) suggest that schools are excellent location for well-being initiatives. Based on growing scientific findings regarding positive psychology, they concluded that well-being should be taught in school. So the counselor candidates could benefit from the courses about positive psychology in order to integrate it in to the school counseling activities and counseling processes.

Although the results of this study have contributed to the literature regarding counselor training, limitations should be considered. First, the current study includes only one experimental group. It wasn't possible to constitute a control group due to the senior GPC students were only one class and all of them trained the positive psychology course. The future experimental studies which will be carried out by experimental group and control group will be more beneficial for evaluating the efficiency of the course. Another limitation of the study is that follow-up measurement was not carried out due to the research was done with the senior undergraduate students. It is suggested to make the follow-up measurements three - six months after the end of the course in the future studies. Finally, only one measurement scale was used in order to evaluate the well-being levels of students. Usage of multi measurement scales (meaning of life, flow experience, positive emotions etc.) will be more beneficial in order to evaluate the course effects with details.

\section{References}

Arıcıoğlu, A. (2013). Psikolojik danışmanın tarihçesi ve mesleki temelleri. N. Voltan Acar (Ed.), Psikolojik danışma: Kapsaml bir meslek. Ankara: Nobel Akademik Yayınc1lık.

Csikszentmihalyi, M. (2009). The Promise of Positive Psychology. Psychological Topics, 18(2), 203-211.

Diener, E., Emmons, R. A., Larsen, R. J., \& Griffin, S. (1985). The Satisfaction with Life Scale. Journal of Personality Assessment, 49, 71-75. http://dx.doi.org/10.1207/s15327752jpa4901_13

Diener, E., \& Chan, M. Y. (2011). Happy People Live Longer: Subjective Well-Being Contributes to Health and Longevity. Applied Psychology: Health and Well-Being, 3(1), 1-43. http://doi:10.1111/j.1758-0854.2010.01045.x

Egan, G. (2011). Psikolojik danışma becerileri. (Çev. Ö. Yüksel). İstanbul: Kaknüs Yayınları.

Eryılmaz, A. (2013). Pozitif psikolojinin psikolojik danışmanlık ve rehberlik alanında gelişimsel ve önleyici hizmetler bağlamında kullanılması. The Journal of Happiness \& Well-Being, 1(1), 1-22.

Gable, S. L., \& Haidt, J. (2005). What (and Why) Is Positive Psychology? Review of General Psychology, 9(2), 103-110. http://doi:10.1037/1089-2680.9.2.103

Grenville-Cleave, B. (2012). Introducing positive psychology: A practical guide. London: Icon Books.

Froh, J. J., \& Parks, A. C. (2013). Activities for teaching positive psychology: A guide for instructors. Washington: American Psychological Association. http://doi:10.1037/14042-000

Fulmer, R. (2015). A History of Happiness: The roots of Positive Psychology, Insight, and Clinical Applications from 2005 to 2015. Ideas and Research You Can Use: VISTAS 2015 Association. http://www.counseling.org/knowledge-center/vistas.

Korkut, F. (2004). Okul temelli önleyici rehberlik ve psikolojik danışma. Ankara: Anı Yayıncılık.

Koydemir, S., \& Kahraman, H. (2015, October). Kampüste Mutluluk: Lisans Düzeyinde Bir İyi Oluş Dersinin Öğrencilerin İyi Oluşları Üzerindeki Etkisi. Paper presented at XIII. National Psychological Counseling and Guidance Congress. Mersin: Mersin University. 
Köker, S. (1991) Normal ve sorunlu ergenlerin yaşam doyumu düzeylerinin karşılaştırılması. Unpublished master thesis. Ankara University, Ankara.

Leech, N. L., \& Onwuegbuzie, A. J. (2007). A typology of mixed methods research designs. Qual. Quant., 43, 265-275. http://doi:10.1007/s11135-007-9105-3

Seligman, M. E. P. (1998). President's column: Building human strength: Psychology's forgotten mission. APA Monitor, 29(1), 1.

Seligman, M. E. P., \& Csikszentmihalyi, M. (2000). Positive psychology: An introduction. American Psychologist, 55(1), 5-14. http://doi:10.1037//0003-066X.55.1.5

Seligman, M. E. P., Steen, T. A., Park, N., \& Peterson, C. (2005). Positive psychology progress: Empirical validation of interventions. American Psychologist, 60, 410-421. http://doi:10.1037/0003-066X.60.5.410

Seligman, M. E. P., Ernst, R. M., Gillham, J., Reivich, K., \& Linkins, M. (2009). Positive education: positive psychology and classroom interventions. Oxford Review of Education, 35(3), 293-311. http://doi:10.1080/03054980902934563

Terjesen, M. D., Jacofsky, M., Froh, J., \& Digiuseppe, R. (2004). Integrating Positive Psychology into Schools: Implications for Practice. Psychology in the Schools, 41(1), 163-172. http://doi:10.1002/pits.10148

Yetim, U. (2003). The impacts of individualism/collectivism, selfesteem, and feeling of mastery on life satisfaction among the Turkish university students and academicians. Social Indicators Research, 61, 297-317. http://dx.doi.org/10.1023/A:1021911504113

Yıldırım, A., \& Şimşek, H. (2005). Sosyal Bilimlerde Araştırma Yöntemleri. Ankara: Seçkin Yayıncılık.

\section{$(\mathrm{Cc}) \mathrm{BY}$}

This work is licensed under a Creative Commons Attribution 3.0 License. 